\title{
Geneza brytyjskiej docusoap i polskiej telenoweli dokumentalnej w kontekście produkcyjno-nadawczym
}

\section{BEATA KOSIŃSKA-KRIPPNER}

Telenowela dokumentalna, będąca - mimo pewnych różnic - polskim odpowiednikiem docusoap, jest już dzisiaj stałym elementem telewizyjnego pejzażu genologicznego, a w związku z tym, że nie jest już nowością, cieszy się mniejszym zainteresowaniem zarówno widzów, jak i realizatorów, skupionych na nowszych, „modniejszych” hybrydach faktualnych ${ }^{1}$. Jednak pierwsze lata XXI w. były okresem prawdziwego rozkwitu i największej popularności telenoweli dokumentalnej, która sprawiała wówczas wrażenie gatunku niezwykle ekspansywnego i niekiedy budziła ogromne emocje widzów, realizatorów i komentatorów ${ }^{2}$. Ponad dekadę wcześniej podobna sytuacja miała miejsce w kontekście docusoap, która pojawiła się na fali powstawania w Europie nowych gatunków telewizyjnych, spokrewnionych z mającą korzenie w USA reality TV ${ }^{3}$. Europejskie publiczne stacje telewizyjne musiały wówczas walczyć o publiczność z coraz liczniejszymi stacjami komercyjnymi. Rozwiązaniem miały być historie z życia prawdziwych ludzi, które zapożyczały styl i środki dramaturgiczne od seriali fikcyjnych, czyli docusoap; ta zaś powstała i z największym powodzeniem rozwijała się w Wielkiej Brytanii.

\section{Początki gatunków granicznych. Brytyjska docusoap}

Realizatorzy docusoap wykorzystali warunki, jakie pojawiły się w produkcji telewizyjnej i strukturze ramówki w określonej fazie historii telewizji. Powstawanie nowych gatunków telewizyjnych, a w szczególności rozkwit coraz nowszych gatunków hybrydowych, ma związek przede wszystkim z poszukiwaniem przez producentów telewizyjnych pomysłów na programy najlepiej wypełniające główne zadanie programu telewizyjnego, któremu podporządkowane są wszystkie inne jego cele. Chodzi tu o zapewnienie stacji jak największej liczby widzów, czyli de facto odpowiednich wskaźników oglądalności i wysokich ocen, od których z kolei zależy zainteresowanie reklamodawców kupowaniem czasu antenowego.

Ogólnie więc tworzenie nowych form czy gatunków ma pozytywnie wpłynąć na sytuację ekonomiczną nadawcy. Zdaniem Brentona i Cohena, w 1998 r. brytyjski film dokumentalny znalazł się w poważnych kłopotach. Tradycja służby publicznej, 
która zapewniała mu - mimo słabej oglądalności - wysoką pozycję w tygodniowych ramówkach, uległa deregulacji. W roku 2012 ich spostrzeżenie potwierdził Kavka ${ }^{4}$. Tradycyjny film dokumentalny, cechujący się powolnym, opisowym tempem, nie należał do programów, które dawały duże dochody z reklam. Chanuel 4, niegdyś kolebka poważnego dokumentu, zastąpił wtedy całe pokolenie redaktorów nowymi, wykształconymi wprawdzie w Oksfordzie i Cambridge, ale wychowanymi na zupełnie innej telewizji niż ich poprzednicy. Młodzi redaktorzy wiedzieli, co przemawia do młodzieży, byli - jak określają komentatorzy - „,bezwstydnie" populistyczni i niezainteresowani starym, „wartościowym” dokumentem. Na dodatek w Wielkiej Brytanii w tym okresie doszło do serii skandali związanych z fałszywymi dokumentami, których realizatorów oskarżano o to, że tworzyli nieprawdziwy przekaz, posługując się rekonstrukcją i zmieniając chronologię wydarzeń. Chodziło głównie o film grupy Carlton o kolumbijskich kartelach narkotykowych, prezentujący sensacyjną, ale faktograficznie wątpliwą teorię, że ulicom brytyjskich miast grozi zalew taniej południowoamerykańskiej heroiny ${ }^{5}$. Gdy za „,narkotykową” aferę ukarano Carltona grzywną w wysokości miliona funtów szterlingów, wróżono rychły upadek filmu dokumentalnego, który zaczął być spychany do coraz późniejszych okienek programowych. Wtedy jednak rozpoczął się jego swoisty renesans - swoisty, bo forma faktualna, która miała wyprzeć z czasu najlepszej oglądalności nawet opery mydlane i filmy obyczajowe oraz zyskać rzesze widzów, przede wszystkim sprawiała wrażenie dokumentu, ale tak naprawdę nim nie była ${ }^{6}$. Na rozwój m.in. docusoap wpłynął w dużej mierze fakt, że brytyjscy nadawcy telewizyjni zauważyli, iż popularna rozrywka faktualna może przyciągnąć szeroką publiczność ${ }^{7}$. Na przykład dla stacji ITV oznaczało to właściwie zniknięcie z programu ITV1 poważnych filmów dokumentalnych, a dla BBC - przy stałej erozji jej cech typowych dla służby publicznej - położenie nacisku na większą przystępność jej programów dokumentalnych, co w praktyce miało oznaczać uzupełnienie repertuaru stacji o programy nowego stylu faktualnie zorientowanej rozrywki, zaprojektowane tak, by przyciągały szeroką widownię.

Ta gotowość nadawców do wzięcia pod uwagę bardziej popularnych form faktualnych utorowała drogę docusoap ${ }^{8}$. Zdaniem Brentona i Cohena w latach 90. wpływowe kręgi świata brytyjskiej telewizji były przygotowane na nową formę dokumentu, gdyż od pewnego czasu redaktorzy programów wspominali o potrzebie filmu faktualnego, opartego na postaci, z wyraźnym wątkiem fabularnym. Za zwiastunkę nowych wymagań, które miały być stawiane w nadchodzących latach programom faktualnym/dokumentalnym, można uznać wypowiedź, jakiej w $1991 \mathrm{r}$. udzielił dziennikarzowi Paul Hamann - ówczesny wydawca, a później szef działu dokumentalnego BBC: Dobre filmy dokumentalne zdobęda odpowiednia publiczność i nie widzę żadnego powodu, by nie mogty mieć dobrego czasu antenowego. Chcę odsunać na bok rządy kolegów z lekkiej rozrywki i filmu obyczajowego ${ }^{9}$. Faktualnymi/dokumentalnymi pracami, które Hamann i jego koledzy z BBC poparli, były między innymi te czerpiące elementy ze sprawdzonych, przetestowanych form i łączące je w nowe, żywotne hybrydy.

W przypadku docusoap mamy do czynienia z formą hybrydową łączącą właściwości dokumentalizmu obserwacyjnego z cechami strukturującymi operę mydlaną. Naturalnie nie można zapominać, że choć docusoap stała się niezmiernie popularna w drugiej połowie lat 90. i została okrzyknięta całkowicie nową i cha- 
rakterystyczną kategorią programów, jej korzenie wywodzą się z wczesnych prób połączenia obserwacji dokumentalnej z dramatycznymi modusami przedstawiania (np. The Family ${ }^{10)}$. Dominujący w połowie lat 90 . styl dokumentalny rozwiną się m.in. dlatego, że został uznany za tańszy od prawdziwego filmu obserwacyjnego. Pojawienie się już w latach 60. XX w. nowych sposobów realizacji filmów niefikcjonalnych zawdzięczamy po części poważnym zmianom sprzętu filmowego. Lżejsze kamery i możliwość rejestrowania dźwięku synchronicznego pozwoliły filmowcom wyjść na zewnątrz i szukać tematów w zupełnie odmienny sposób niż dotychczas. Wiele obszarów rzeczywistości stało się dla nich bardziej dostępnymi. Potrzebowali mniej sztucznego światła, dzięki czemu filmowanie mogło być bardziej spontaniczne. Twórcy spod znaku direct cinema i cinéma vérité postrzegali bezpośredniość, natychmiastowość i intymność jako ,prawdziwe” w opozycji do starannie zaplanowanej, przygotowanej dramaturgii i „gładkiego" wyglądu tradycyjnego kina oraz zrekonstruowanej rzeczywistości wcześniejszych dokumentów ${ }^{11}$. Podobne zmiany techniczne zaszły wiele lat później i umożliwiły ekipom realizującym brytyjską docusoap Driving School czy norweską Klar, ferdig, kjør np. umieszczenie kamery na desce rozdzielczej samochodu.

Gatunek docusoap mógł zatem powstać dzięki spełnieniu kilku wstępnych warunków technicznych, społecznych, ekonomicznych i związanych z mediami ${ }^{12}$. Wśród technicznych należy wymienić łatwo dostępny i tani w eksploatacji sprzęt wideo. Obok standardowych cięższych kamer Beta pojawiły się małe, lekkie, ręczne kamery cyfrowe, umożliwiające obserwację oraz szybką i elastyczną reakcję na to, co się dzieje. Dzięki takim kamerom zdjęcia mogły realizować dwie, a nawet jedna osoba, co sprzyjało intymizacji. Równie ważną rolę odegrały tu oddzielne dla każdego bohatera źródła rejestracji dźwięku (maleńkie, bezprzewodowe, przypinane mikrofony lub MD), które gwarantowały intymny i bezpośredni dźwięk w wypowiedziach bohaterów (w odróżnieniu od dźwięku komentarza z offu) i dużo większą swobodę filmowania. Warunkiem społecznym było upowszechnienie się kamer wideo i zwyczaju wizualnego dokumentowania prywatnych wydarzeń oraz rosnąca popularność web-kamer. W swej społecznej funkcji amatorskie filmy wideo i web-kamery stały się rodzajem prekursorów docusoaps. Warunkiem koniecznym dla powstania docusoap było też przekroczenie granic między prywatnym i publicznym w dyskursie medialnym i społecznym. Warunkiem ekonomicznym było to, co Lutz Hachmeister nazwał w latach 90. nowa ekonomia dokumentu na oznaczenie globalnego niefikcjonalnego przemystu, z jego stała zmiennościa ${ }^{13}$. Chodzi tu o fakt, że po długim okresie, w którym dokument był właściwie produktem niszowym, przyciągnął on uwagę globalnego marketingu. I chociaż historie oraz struktura narracji ciągle były zakorzenione w lokalnych strukturach kulturowych i językowych, to zaczęto eksportować idee, pomysły i formaty, które musiały być zaadaptowane do importującego je kraju. Jako warunki dotyczące mediów Margreth Lünenborg podawała zmieniające się przyzwyczajenia widzów, które wymagały nowych form dokumentalnych. Jej zdaniem coraz trudniej było na początku XXI w. umieścić w ramówce 120-minutowy dokument. Skoro telewizja zaczęła być postrzegana jako medium serialowe, to dokument potrzebował pasujących do niej nowych form. Jedną z nich stał się właśnie dokument serialowy. Drugim warunkiem związanym z mediami było zniesienie ustalonych różnic między reprezentacjami rzeczywistości a spektaklem, publicznym i prywat- 
nym, między serialowymi opowieściami i niefikcyjnymi filmami oraz telewizją ${ }^{14}$. Ta mieszanka form była czymś prototypowym, jeszcze nierozpoznanym przez widza, co nadawcom publicznym dało możliwość użycia specyficznych środków w pracach dokumentalnych i znalezienia nowych sposobów prezentowania, które brały pod uwagę zmianę struktury i zainteresowań publiczności.

Ważną rolę odegrały tu też przemiany, jakim zaczęło podlegać dziennikarstwo. Z jednej strony zacieśniał się związek realności z rozrywką telewizyjną, a z drugiej dziennikarstwo coraz częściej używało technik scenariuszowych i inscenizacyjnych rodem z programów fikcjonalnych. Obok konwergencji technicznej zaczęła się pojawiać specyficzna forma konwergencji treściowej. Filmy dokumentalne, dziennikarstwo, fikcja i rozrywka już nie moga być od siebie oddzielane, a to prowadzi do tworzenia nowych mieszanych gatunków ${ }^{15}$ - pisała w 2002 r. Lünenborg. W badaniach nad mediami zmiana ta jest opisywana różnymi terminami, m.in. jako performatywna reality $T V^{16}$, przy uwypukleniu nowej idei rzeczywistości w rozrywce telewizyjnej; jako telewizja afektywna ${ }^{17}$ - pełna emocji, przy wskazywaniu gatunków, które nie są fikcjonalne i roszczą sobie pretensje do przedstawiania rzeczywistości, a nawet tę rzeczywistość kreują; i po prostu jako reality TV.

Określenie ,gatunki graniczne” pojawiło się w sierpniu 1999 r. podczas zorganizowanego na University of California w Los Angeles panelu zatytułowanego Border Genres: Facts, Fictions and Spaces Between. Do kategorii gatunków granicznych należą filmy i programy telewizyjne, które zajmują czy wręcz wykorzystują przestrzeń między niefikcyjnym i fikcyjnym oraz obejmują cztery główne podgatunki/obszary programowe, które z kolei przebiegają w spektrum od prawie dokumentu (almost documentary) reality TV, przez wysoce znarratywizowaną (highly-narrativised) docusoap i na poły fikcjonalizowaną (semifictionalised) docudramę, do fikcjonalnego (ale wyglądającego jak dokument) mock-dokumentu. Jak relacjonował Derek Paget, był to świadomy zwrot ku dwóm głównym elementom takich realizacji - recepcji i produkcji. Uczestnicy panelu chcieli zaznaczyć zarówno nieszczelną/porowatą (porous) naturę, jak i nieuzasadnioną reputację takich programów. Wykorzystali wyraźne obawy, jakie wyłoniły się w kulturze we wczesnych latach 90., dotyczące zamazywania się takich właśnie granic (zwłaszcza odnośnie do dokumentu telewizyjnego). Termin ten był wystarczająco wygodny, ale w związku z kryzysem idei autentyczności dokumentu, panującym w kulturze końca XX w., używano go obok pojęcia „hybrydowość”. Gatunki graniczne uosabiały dla uczestników panelu tendencję do hybrydyzacji w coraz bardziej zagmatwanym środowisku mediów końca wieku, charakteryzującym się zalewem komentarzy, kryzysem zaufania do granic i ram, kwestionowaniem historycznych roszczeń dokumentu (czy wręcz mediów wizualnych w ogóle) do relacjonowania rzeczywistości.

Podstawową cechą dystynktywną telenoweli dokumentalnej (i docusoap) jest połączenie dokumentalnej metody realizacji ze strukturą tasiemcowego serialu. Cecha ta ma duże znaczenie dla efektywności realizacji jednego z głównych celów gatunków hybrydowych, czyli podwyższania wskaźników oglądalności. Mirosław Przylipiak podkreślał, że właściwością, którą telewizja wniosła do dokumentalizmu, jest właśnie poddanie obrazu telewizyjnego prawom serii i że wynika to z przyczyn ekonomicznych. Seryjność jest szansa na utrzymanie przy odbiornikach większej liczby telewidzów przez dhuższy czas. W kategoriach czysto ekonomicznych 
nastepuje zwiazanie konsumenta z produktem, a więc sytuacja przez wszystkich producentów wymarzona. Cena za to jest standaryzacja produktu zwiększajaca szansę przyciagnięcia jak największej liczby odbiorców ${ }^{18}$. Wieloczęściowe formy dokumentalne pojawiły się w telewizji dość wcześnie w postaci serii oraz cykli i przez lata dotyczyły filmów edukacyjnych, historycznych ${ }^{19}$, a w końcu przyrodniczych. Wieloodcinkową formę miały też programy typu „ukryta kamera”, np. amerykańska i kanadyjska seria Candid Kamera (wyprodukowane przez „Unit B” kanadyjskiego National Film Board) czy Living Camera (prod. Drew Associates). Również polska telewizja prezentowała rodzime i zagraniczne wieloczęściowe formy dokumentalne: serie i cykle popularno-naukowe, historyczne, przyrodnicze i - do późnych lat 90. głównie importowane - programy typu „ukryta kamera”.

W kontekście telenoweli dokumentalnej (i docusoap) trzeba jednak sprecyzować terminologię, gdyż to nie seryjność (jak się potocznie określa schemat, w którym kolejny odcinek nie jest fabularnie uzależniony od poprzedniego) jest tak istotną cechą docusoap, ale - tak to nazwijmy - serialowość czy serializacja, którą przejęła ona bezpośrednio od opery mydlanej i która determinuje część z jej podstawowych cech, odróżniających, a właściwie znacznie oddalających ją od wczesnych, wspomnianych wyżej wieloczęściowych form dokumentalnych. Jak wspomniałam na początku, w Wielkiej Brytanii w próby łączenia twardego ostrza dokumentu z bardziej miękkimi właściwościami opery mydlanej ${ }^{20}$ ekipy produkcyjne były zaangażowane już na początku lat 90 ., kiedy nadawcy działający w służbie publicznej zostali wciągnięci w silne współzawodnictwo z ich komercyjnymi rywalami, co wytworzyło klimat sprzyjający rozwojowi takich formatów, jak docusoap. BBC zaczęła szukać dróg rozszerzenia bazy jej faktualnych/dokumentalnych dokonań, produkując formy silnie odwołujące się do rozrywki. Wewnętrzni producenci byli zachęcani do rozwijania pomysłów na programy oparte na faktach, które mogłyby oznaczać odejście od statecznych, poważnych dokumentów, z którymi $\mathrm{BBC}$ była dotychczas kojarzona. Zdaniem Kilborna, nigdzie te zmienione priorytety nie były bardziej wyraźne niż w podejściu do ramówki i zamówień. W latach 80. - jak wspominat mi w wywiadzie Jeremy Mills - ciagle istniała wśród producentów wewnętrznych z BBC powszechna praktyka robienia programów, a potem oczekiwania na znalezienie odpowiedniego czasu antenowego w ramówce. Jednak w latach 90., kiedy nadawcy zaczęli odczuwać mroźny powiew konkurencyjnego rynku kultury, robienie programów stało się operacją dużo bardziej sterowana ramówką. Konkretne potrzeby programowe zostały utożsamione ze spetnianiem specyficznych wymagań ramówki i zajmujący się jej układaniem zaczęli mieć coraz większy wpływ na decyzje dotyczace typu programów, które były zamawiane, zwłaszcza do pasma prime-time, w którym rywalizacja była największa ${ }^{21}$. Docusoaps były więc reakcją grupy czujnych, przedsiębiorczych realizatorów na wymogi telewizyjnej ramówki dotyczące formy programów bazujących na rzeczywistości, które mogłyby wygenerować dużą, doceniającą je publiczność w czasie największej oglądalności.

Potrzeby ramówki telewizyjnej częściowo wyjaśniają, dlaczego docusoap wysunęła się tak gwałtownie na przód w połowie lat 90. Jej szybka proliferacja była rezultatem zarówno ogólnego zapotrzebowania na lekkie, łatwiejsze do przyswojenia formy rozrywki faktualnej, jak i określonego zespołu warunków, które wpływały na repertuar programów $\mathrm{BBC}$ w tym czasie. Do połowy lat 90 . osoby 
układające ramówkę mogły polegać na kombinacji uznanych formatów, by dostarczyć wymagane wskaźniki pasmom wieczornej ramówki. Efekty wzrastającej rywalizacji, ujawnione w zmniejszającej się widowni, przyniosły potrzebę zamawiania nowych prac, które - przy niskich kosztach - przywróciłyby widzów utraconych na rzecz innych kanałów. W takim właśnie momencie osoby planujące program w BBC, przywołując sukcesy wcześniejszych seriali faktualnych The Vet (BBC1, 1989) i The Doctor (BBC1, 1990), zamówiły u wewnętrznych ekip wyprodukowanie seriali faktualnych, które łączyłyby techniki dokumentu obserwacyjnego z technikami popularnych fikcji dramatycznych ${ }^{22}$. I jak pisał Kilborn, potrzeba formy skoncentrowanej na postaciach i należącej do opartej na faktach rozrywki zaowocowała powstaniem dwóch seriali, które z powodzeniem ustanowiły złoty standard dla przyszłych produkcji docusoap. Był to sześcioczęściowy serial Aiport (BBC1, 1996) z akcją umiejscowioną na londyńskim lotnisku Heathrow, oraz Driving School (BBC1, 1997), ukazujący perypetie osób próbujących zrobić prawo jazdy. Wielki boom docusoap w Wielkiej Brytanii miał miejsce w latach 1995-2000 23; np. w roku 1998 nadawano tam 75 różnych docusoaps. Ich akcja rozgrywała się w operze, na lotnisku, w szkole nauki jazdy, na statku wycieczkowym, na wsi, w hotelu, na farmie zdrowia. Wiele z nich nadawano w paśmie prime-time, rywalizując z popularnymi programami, a niekiedy nawet je wypierając, jak choćby tasiemcowe opery mydlane Eastenders czy The Bill. Gail Coles zauważyła, że proliferacja docusoaps była wynikiem kryzysu, w jakim znalazły się programy nadawane wczesnym wieczorem. Sitcomy i teleturnieje traciły publiczność, a przez połączenie elementów rzeczywistości z elementami komedii oraz spektaklu w formacie serialowym ożywiono wczesnowieczorną ramówkę ${ }^{24}$. Mal Young dodawał: Ludzi zacząt powoli nudzić styl dokumentalny. Widzowie odkryli, że postać i fabuła są dwoma potężnymi czynnikami każdego telewizyjnego show, wziętymi bezpośrednio z popularnego filmu obyczajowego ${ }^{25}$. Producent docusoap Andrew Bethell twierdził, że stanowiła ona najbardziej znaczący postęp w najnowszej telewizji brytyjskiej ${ }^{26}$. Entuzjazm ten podzielali także inni producenci, twierdząc czasem, że nowe formaty, jakie powstały z powodu wspomnianych przemian, przeorały nową ziemię i były stylistycznie innowacyjne.

Forma ta od momentu powstania budziła emocję i krytykę. Niektórzy komentatorzy wprawdzie bez większego entuzjazmu, ale jednak dostrzegali jej aspekt pozytywny, jak np. Brian Winston, który twierdził, że docusoap była ceną przetrwania dokumentu w ramówkach brytyjskich stacji telewizyjnych, z których powoli zaczął znikać, podobnie jak ze stacji amerykańskich ${ }^{27}$. Inni komentatorzy, jak Richard Kilborn, podchodzili z większym sceptycyzmem niż producenci zarówno do ,,innowacyjności” docusoap, uważając ją wyłącznie za połączenie elementów uznanych formatów telewizyjnych, jak i do jej ,ratunkowej” funkcji, twierdząc, że podniosła ona jedynie statystycznie oglądalność i to nie filmów dokumentalnych, ale ogólnie programów faktualnych. Jednak ponad 12 mln widzów, których zgromadził jeden z odcinków Driving School (BBC1), pokazany 15 lipca 1997 r., robiło wrażenie. Stella Bruzzi pisała, że redaktorzy zamawiający nie mogli się oprzeć docusoap, kiedy po raz pierwszy w historii brytyjskiej telewizji programy faktualne zaczęły regularnie osiągać wyższą oglądalność niż telewizyjne filmy obyczajowe. Znaczące - jej zdaniem - było również to, że podobieństwo docusoap do popularnych dramatów pozwalało zatrzymać dużą część tej samej publiczności ${ }^{28}$. Głosy 
dezaprobaty i krytyki, jakie wywoływała docusoap, zdobywając sobie coraz mocniejszą pozycję w brytyjskich ramówkach w okresie 1996-1999, wyrażały pogląd, że jej rosnąca popularność jest dowodem na upadek telewizji oraz że zachęca uczestników do dawania upustu amatorskim dramatom ${ }^{29}$. Obawiano się, że wzrost pozycji tej formy przyczyni się do dalszej marginalizacji podnoszącego świadomość dokumentu. Jeden z obserwatorów powiedział: Docusoaps sa uważane przez redaktorów zamawiających i osoby układające ramówkę za rozwiązanie doraźne, które zapewnia duża widownię za ułamek kosztów wysokiej jakości filmu obyczajowego. Wszyscy ich chca. Istnieje jednak niebezpieczeństwo, że w goraczce dostarczania coraz większej ilości, jakość się obniży $i$ standardy nie zostana utrzymane ${ }^{30}$. Nadawcy natychmiast stanęli w obronie docusoap, sugerując, że jej ciepłe przyjęcie przez publiczność było oznaką ogólniejszego rozbudzenia zainteresowania formatami faktualnymi ${ }^{31}$. Oskarżenie, że jest ona tylko motorem lekkiej rozrywki, niezdolnej nawet do tego, by się zbliżyć do jakiejś tezy ${ }^{32}$, było odpierane podkreślaniem, że docusoaps gatunkowo nie mają być lekkie, puste i pozbawione treści.

Niektórzy badacze uznali przyhamowanie tempa rozwoju docusoap po roku 2000 za niemalże jej upadek. Kilborn twierdził na przykład, że jej wcześniejszy błyskawiczny wzlot dorównuje jedynie prędkości, z jaką powróciła z powrotem na ziemię ${ }^{33}$. Uzasadniał on ten fakt po pierwsze wyczerpaniem się potencjalnych tematów, spowodowanym - jak to ujął - istnym szaleństwem wśród twórców programów i rywalizujących kanałów, jakie wybuchło po nieoczekiwanym wzroście popularności seriali Airport, Driving School i Vets in Practice, kiedy wszyscy zaczęli przedstawiać własne propozycje docusoap; po drugie - zmęczeniem publiczności, a tym samym zmuszeniem redaktorów zamawiających do poszukiwania innych form rozrywki faktualnej, która zaspokajałaby potrzeby ramówkowe; zaś po trzecie - pewnymi obawami dotyczącymi wizerunku BBC, która w latach 1996-1998 wyraźnie uznała siebie za lidera rynku w repertuarze docusoap i pokazała w tym czasie nie mniej niż trzynaście seriali tego typu (w opozycji do czterech pokazanych przez inne kanały naziemne) ${ }^{34}$. Producenci wykonawczy BBC zaczęli wyrażać obawy, że stacja ta zbytnio polega na popularnych formatach faktualnych i że nadmierne zamawianie docusoap może mieć negatywne implikacje dla bardziej wymagających form „poważnego” dokumentu, z którymi BBC była tradycyjnie identyfikowana ${ }^{35}$. Również krytyka uznała, że rozpowszechniające się klonowanie przyniosło gatunkową utratę wigoru. Serial Dover (1997) z ITV został na przykład uznany za mizerną, nieudaną imitację serialu BBC Airport, a Chalet Girls (ITV, 1998), który dotyczył młodych kobiet na wydaniu, pracujących w przemyśle turystycznym, był - zdaniem recenzentów - odcinaniem kuponów od Holiday Reps (BBC1, 1997) ${ }^{36}$.

Pod koniec 2000 r. docusoaps nie były już tak silnie obecne w ramówkach wszystkich brytyjskich nadawców, jak to miało miejsce trzy lata wcześniej. I tak jak w latach swego bezprecedensowego sukcesu w Wielkiej Brytanii (1996-2000) docusoap była we wszystkich wieczornych ramówkach nadawców głównego nurtu, zwłaszcza BBC1, tak z końcem wieku zauważono zmęczenie widzów. Zamawianie oraz emitowanie docusoaps zostało więc drastycznie zredukowane ${ }^{37}$. Jak stwierdził Kilborn, nadawcy sami przyznali, że chcąc utrzymać uwagę widzów, zbytnio zaufali temu gatunkowi. W XXI w. pojawiły się w Wielkiej Brytanii nowe formy fak- 
tualne i niektóre z nich stały się bardzo popularne wśród publiczności, zwłaszcza te $\mathrm{z}$ kategorii game-doc i survivor. Docusoaps były nadal produkowane, jednakże w znacznie mniejszej liczbie. Niektóre, np. Airport (1996-2005, 2008) i Airline (1998-2007), okazały się naprawdę długie. Zawdzięczały to - jak przypuszczał w 2003 r. Kilborn - umiejscowieniu w porcie lotniczym, z dziesiątkami tysięcy podróżnych wyjeżdżających na wakacje lub w interesach i tysiącami pracowników zaspokajających ich potrzeby, które jest idealną lokacją do obserwowania konfrontacji oraz wymiany zdań i emocji ${ }^{38}$. Kilborn miał rację, bo kolejne lata przyniosły wiele brytyjskich docusoaps związanych z lataniem: m.in. Animal Airport (2000, 2012), Holiday Airline (2001), Luton Airport (2005-2008), Nothing to Declare UK (2008), UK Border Force (2008-2009), Heathrow: Britain's Busiest Airport (20152019), EasyJet: inside the Cockpit (2017-2019). Po roku 2000 docusoap jako gatunek całkowicie nie zniknęła i w czystej formie jest od czasu do czasu wykorzystywana, ale jej miejsce w ramówce zajęły nowe formaty reality, które czasem zawierają szczątkowe ślady docusoap, ale wykazują znaczące odejście od docusoapowych scenariuszy i zainteresowań. Nowe formaty są wyrazistsze, śmielsze i mają silniejszy element voyeurystyczny. Są one również - jak podkreślił Kilborn - bardziej skoncentrowane na akcji i kładą większy nacisk na rozwijanie strategii angażowania publiczności. To, co nastąpiło po roku 2000 (zresztą nie tylko w Wielkiej Brytanii), należy uznać za koniec wielkiego boomu docusoap.

\section{Pierwsze docusoaps w innych krajach}

Pierwsze sukcesy tego gatunku w Wielkiej Brytanii sprawiły, że zaczął się on rozprzestrzeniać na inne kraje, m.in. na Niemcy, gdzie od końca lat 90. pojawiło się wiele seriali określanych tym mianem, np. Geburtsstation (ARTE, SFB, 1999, real. Thomas Kufus, Arpad Bondy, 4 odc.) - relacja z oddziału położniczego, $A b$ nehmen in Essen (WDR, dwie serie 2000-2001) ${ }^{39}$ o pięciu kobietach próbujących się odchudzić, Geburtsstation (ARTE $\backslash$ RBB, 2003, real. Corinna Belz), Einer für alle (MDR, 2004) o dniu powszednim strażaków z Miśni należących do najstarszej w Niemczech - założonej w 1841 r. - Ochotniczej Straży Pożarnej, Eine Couch für alle Felle (WDR, 2003), Elefant, Tiger Co (MDR, 2003-2019), Pinguin, Löwe \& Co (WDR, 2006-2007), Giraffe, Erdmännchen \& Co (HR, 2006-2018), Seehund, Puma \& Co (RB, 2007--2015). W Niemczech, gdzie docusoap znalazła bardzo podatny grunt do rozwoju ${ }^{40}$, na początku XXI w. tę bulwarową tradycję podchwycili w przeciwieństwie do innych krajów - prywatni nadawcy telewizyjni, którzy początkowo zaczęli masowo adaptować formaty zagraniczne, m.in. brytyjskie. I tak z Driving School powstała Die Fahrschule (SAT1, 1999), z The Cruise narodził się Clubschiff(RTL, 1999), a z Vets - Die Tierklinik (ZDF, 1999). Jednak jak napisał Fritz Wolf ${ }^{41}$, dość szybko okazało się, że zwykłe przejmowanie nowego formatu wcale nie będzie takie łatwe. Po pierwsze było to droższe niż zakładano i bardziej skomplikowane. Kręcenie materiału na statku wycieczkowym (jak miało to miejsce w wypadku Clubschiff) przez cztery ekipy operatorskie, a potem niedbałe montowanie po prostu się nie opłacało. Jakość docusoap wymagała innej organizacji: podziału pracy podczas produkcji, wyższych nakładów na montaż, lepszej jakości dźwięku, inteligentnej, przemyślanej dramaturgii. Zdaniem Wolfa, docusoap wcale nie jest tanim formatem telewizyjnym. A przynajmniej nie była tania realizacja 
w niemieckich warunkach niektórych docusoapowych formatów. Nadawcy publiczni uwierzyli natomiast w dokumentalny potencjał formatów, mając nadzieję, że dzięki nim można poszerzyć obszar wszystkich dokumentów, skupić się na nowych tematach i być może przy użyciu sprawdzonego wzorca komercyjnego przyciągnąć widzów, którzy zazwyczaj unikali programów dokumentalnych. W związku z tym stosunkowo wcześnie w europejskim kanale kulturalnym Arte i berlińskim SFB pojawił się - realizowany przez cały wrzesień 1998 r. - serial Geburtsstation (1999) Thomasa Kufusa i Artada Bondy, a Abnehmen in Essen (1999-2001) z WDR otrzymał nagrodę Adolfa Grimme (2000) za innowacyjność programową, zaś telewizja SWR z Baden-Baden zrealizowała Broadway Bruchsal (SWR, 2001) Dominika Wesseleya i Marcusa Vettera (nagroda Adolfa Grimme, 2002) i Ein Kind aus der Ferne (Südwest 2002, 2006) Caroline Goldie. Kanał kulturalny Arte nadawał docusoaps od poniedziałku do piątku od godziny 20.15 do 20.45 , czyli w paśmie prime-time ${ }^{42}$. Serial Geburtsstation pozwolił uczestniczyć widzom w intymnych chwilach szczęścia i wzruszenia świeżo upieczonych rodziców. Przedstawiciel Arte Hans Robert Eisenhauer określił tę produkcję jako próbę umożliwienia widzom wglądu w środowisko i sytuacje, które zwykle są widowiskowe, podniecające i przerażające. Z punktu widzenia Bondy'ego podjęcie przez Arte, SFB i Zero Film tego projektu było nową formą uniknięcia ostatecznego wyrugowania filmów dokumentalnych z oferty telewizyjnej ${ }^{43}$.

Do połowy 2001 r. prywatni i publiczni nadawcy w Niemczech emitowali ponad 46 docusoaps. Ciekawostką jest, że tamtejsi nadawcy publiczni kładli nacisk na eksponowanie dokumentalności tych programów, co się przejawiało m.in. w języku, czyli po prostu w nieużywaniu terminu docusoap na określenie ewidentnie „mydlanych" dokumentów. Gatunek ten rozwijał się w Niemczech dwutorowo. Niektórzy prywatni nadawcy byli nastawieni na tanie warianty i tym samym zdyskredytowali całą formę. W ich rozumieniu docusoap była rodzajem komedii z nieprofesjonalnymi odtwórcami, która niechętnie korzystała z wyrafinowanych chwytów narracyjnych. Przykładem będzie tu serial Schnulleralarm (RTL 2, 2001), cieszący się powodzeniem, ale pozostający pod względem estetycznym i narracyjnym na niskim poziomie ${ }^{44}$. Zdaniem Wolfa nadzieja na to, że docusoap otworzy przed telewizją nowe rejony, spełniła się tylko częściowo, gdyż wiele programów skłaniało się ku tematom dnia powszedniego, które i tak często pojawiają się w reportażach. Jednak dzięki np. Frauen am Ruder (2003) czy Frauen in der Bundeswehr (2003) na horyzoncie pojawiły się interesujące tematy społeczno-polityczne, a Endemol, producent Big Brothera, odważył się - wprawdzie, jak twierdzi Wolf, bez planu i pomysłu, ale nadzwyczaj powściągliwie - poruszyć temat bezrobocia w 11-odcinkowej docusoap Artern - Stadt der Träume (2003), reprezentującej socialtainment, do której Endemol przeprowadził casting 12 niemieckich miast. Martina Zöllner z telewizji SWR uznała tego typu seriale dokumentalne za format odpowiedni do „małych” tematów: Podczas gdy duży film dokumentalny musi niekiedy - formalnie i treściowo - szukać ,nadzwyczajnego”, wieloczęściowy dokument nadaje się do opowiadania ,, małych”, pisanych przez życie historii, które mimo to sa petne dramaturgii. Bohaterowie seriali dokumentalnych sa bohaterami dnia powszedniego, a tym samym postaciami, z którymi można się utożsamić ${ }^{45}$.

$\mathrm{Z}$ ówczesnych doniesień prasowych ${ }^{46}$ wynika, że w stacjach niemieckojęzycznych właściwym czasem docusoap był sezon telewizyjny 2004/2005, choć 
należy pamiętać, iż w Niemczech dość często tym mianem określa się rozmaite programy z rodziny reality TV, które formalnie docusoap nie są, jak np. Frauentausch. „Mydlane” seriale dokumentalne realizowano też z dala od Europy. Przykładem jest tu najprawdopodobniej pierwsza kanadyjska docusoap powstała w 1998 r. ${ }^{47}$ Wyprodukowana przez Davida Paperny'ego i Audrey Mehler dla CBC Vancouver's Broadcast One Brewery Creek opowiadała o życiu mieszkańców odnowionego budynku w dzielnicy Strathcona w Vancouver, ukazując w czteroczęściowym serialu takie tematy, jak szukanie pracy, kradzieże samochodów, prostytucja i ciąża. Serial emitowano „na raty” po 8-10 minut podczas emisji serwisu informacyjnego w każdy poniedziałek marca 1998 r. Z kolei w Skandynawii docusoap pojawiła się w tym samym czasie, co w Polsce. W Danii najlepszą oglądalność miał serial Stripperkongens piger (The Girls of the Striptease King, TV Denmark, 1999), który był zarazem najchętniej oglądanym programem tego kanału. W Szwecji pierwsze odcinki Sjukhuset (TV4, 1999) oglądalnością ustępowały tylko wiadomościom. W Norwegii taką pozycję uzyskał serial Klar, ferdig, kjør (TV Norge, 1999) - remake Driving School. Na wiosnę roku 2000 pokazywano tam m.in. w paśmie prime-time TV2 brytyjski format Dyreparken (The Zoo), a w paśmie kolejnym w NRK1 - skierowany do młodzieży Vi er Val'enga (We are Val'enga). Zdaniem Ruoffa docusoap (przynajmniej w USA i Wielkiej Brytanii) stanowiła w strukturze dziennego programu telewizyjnego pomost między nadawanymi w dzień operami mydlanymi a programami faktualnymi z pasma prime-time ${ }^{48}$. Z kolei Lünenborg zauważyła, że w Niemczech i Francji, a zwłaszcza na francusko-niemieckim kanale kulturalnym Arte (głównym producencie docusoap) czas emisji tych seriali (20.25-20.45) pomagał ustalić początek telewizyjnego czasu największej oglądalności i miał symboliczny wkład w zsynchronizowanie tych dwóch różnych kultur telewizyjnych ${ }^{49}$.

\section{Początki i rozkwit telenoweli dokumentalnej}

Geneza telenoweli dokumentalnej jest mniej złożona i trochę inna niż docusoap, choć wiele aspektów łączy obie te formy. Pojawiła się w Polsce w momencie, kiedy m.in. Ewa Borzęcka i Marcin Koszałka oswajali polską publiczność z nowym, łamiącym rozmaite tabu stylem pokazywania rzeczywistości w filmach dokumentalnych (Trzynastka /1996/, Arizona /1997/, Oni /1999/, Takiego pięknego syna urodziłam /1999/). Z nową formą telewizyjną ,serializującą” rzeczywistość polscy widzowie mieli okazję zaznajomić się dość wcześnie, bowiem za prekursorów polskiej telenoweli dokumentalnej można uznać dwa seriale zrealizowane dla Telewizji Polskiej w latach 1977-1978 przez Jerzego Śladkowskiego i Stanisława Krzemińskiego. W środowisku dokumentalistów tego typu idee krążyły - powiedział Krzemiński - gdzieś się to pojawiało, choć nasi dokumentaliści nie wiedzieli wtedy o istnieniu ,, The Family” czy „, The American Family”. Jak mówił, pierwsze polskie seriale, które można nazwać telenowelami dokumentalnymi, to Dzień po dniu: Kędzierzyn Koźle oraz Dzień po dniu: Puławy i były emitowane w paśmie o nazwie „Siódemka” między dobranocką a dziennikiem. Struktura tych seriali była typowo docusoapowa: ci sami bohaterowie śledzeni przez wiele tygodni, a na antenie pokazywani przez wszystkie sześć odcinków (dzień po dniu), od poniedziałku do soboty. Oczywiście nikt wtedy nie mówił o docusoap czy tele- 
noweli dokumentalnej, ale seriale te były najbliższe ich modelowi. Dokumentacja do sześciu odcinków pierwszego serialu trwała dwa i pół miesiąca, do drugiego prawie trzy miesiące. To byt luksus tamtej sytuacji. TVP nie miała konkurencji. Nikt aż tak na wyniki ekonomiczne nie patrzyt, jak dziś ${ }^{50}$ - powiedział laureat Felixa (1996) za wkład w rozwój europejskiego filmu dokumentalnego, Stanisław Krzemiński, który do podobnej formy, tym razem już świadomie nazwanej telenowelą dokumentalną, powrócił po wielu latach, stając się pomysłodawcą i producentem pierwszej polskiej docusoap - Szpitala Dzieciątka Jezus (1999). Wspominając tamten moment, stwierdził, że pomysł, by zająć się tą właśnie formą, zrodził się w sposób naturalny, zwłaszcza że w 1998 r. brał konsultantem przy niemieckiej docusoap Flughafen (prod. ZDF). Ponieważ moim środowiskiem naturalnym jako producenta przez lata byt dokument, a w Europie zaczęło się o tym coraz głośniej mówić, zaczałem zabiegać o to, by móc robić taka forme - powiedział ${ }^{51}$. Pierwsze założenia tego 29-odcinkowego serialu Krzemiński zapisał we wrześniu 1996 r. Na rozpoczęcie realizacji czekał dwa lata, w końcu w 1998 r. Nina Terentiew, ówczesna szefowa TVP2, postanowiła podjąć ryzyko produkcji. Sytuacja była więc odwrotna niż w Wielkiej Brytanii, gdzie inicjatywa wyszła od nadawców telewizyjnych, którzy zachęcali producentów do realizacji tego typu programów. Krzemiński i Terentiew stali się „rodzicami” telenoweli dokumentalnej. Kiedy zakończono pracę nad serialem, na stronie internetowej producenta napisano: Telenowela dokumentalna - tego gatunku jeszcze polscy widzowie nie znaja.

Serial wyprodukowała dla TVP2 spółka Besta Film. Podjęcie realizacji nowego w Polsce formatu wynikało z inspiracji zagranicznych, naturalnych dla polskich dokumentalistów mających rozeznanie na rynku europejskim, oraz z chęci przeniesienia go na grunt polski w formie atrakcyjnej dla rodzimego widza. Miejscem akcji pierwszej polskiej docusoap jest I Szpital Kliniczny Akademii Medycznej w Warszawie im. Dzieciątka Jezus. Przez ponad miesiąc (październik i listopad 1998 r.) autorzy przygotowywali się do pracy, rozmawiając z dziesiątkami lekarzy i ponad setką pacjentów. Potem, po wybraniu bohaterów, przez osiem tygodni ekipa filmowa realizowała zdjęcia na kilku oddziałach szpitala. Aktorami tego serialu są rzeczywiste postaci: lekarze, pielęgniarki oraz pacjenci z ich prawdziwymi dolegliwościami, stresami, zwycięstwami i klęskami. Kamera towarzyszy im w domach, w drodze do szpitala i w samym szpitalu, jak przygotowują się do przeszczepów, jak uczestniczą w zabiegach i rutynowych badaniach. Oprócz pacjentów widzowie poznają również personel medyczny, obserwując go zarówno w pracy, jak i w życiu prywatnym. Autorami Szpitala Dzieciątka Jezus są reżyserzy filmów dokumentalnych - Nono Dragović i Grzegorz Siedlecki. W tym czasie inspiracją dla polskiego serialu mogły być np. brytyjska „szpitalna” docusoap o pacjentach, personelu medycznym i innych pracownikach szpitala dziecięcego w Sheffield pt. Children's Hospital (BBC1, 1993-2003) czy o londyńskim szpitalu Great Ormond Street Hospital (BBC1, 1996). Najpierw zamówiono u nas trzy odcinki, potem następne wspominał Grzegorz Siedlecki. Producent wiedziat, że na Zachodzie docusoap odnosi sukcesy, ale nie byto pewności, czy u nas się przyjmie, mimo że korzystaliśmy ze sprawdzonych pomystów, pokazując np. szpital i przeszczep nerki, która żona oddała mężowi ${ }^{52}$. Autorzy zdecydowali się na szpital jako miejsce akcji z kilku powodów. Po pierwsze dlatego, że gatunek ten opiera się na emocjach, a tych w szpitalu jest wiele. Stanisław Krzemiński powiedział: Szpital byt po prostu miejs- 
cem, które gwarantuje dramaturgię. Sa dwa takie miejsca, o które chciałem się zaczepić: albo szpital, albo rodzinny zakład pogrzebowy, ale w naszej kulturze ten drugi temat jest nie do ugryzienia, choć tam emocje sa na wyciagnięcie ręki. Realizatorzy wybrali Szpital im. Dzieciątka Jezus, bo tam lekarze najpełniej zrozumieli ich intencje i uwierzyli, że nie chodzi o epatowanie widowni sensacjami, lecz o pokazanie ludzkiego losu i ciężkiej pracy. Krzemiński powiedział: Dyrekcja tego szpitala podjęła ryzyko. Zadecydowała tu otwarta głowa dyrektora. Inni się bali, bo byto to coś nowego, a przecież musieli na gębę zaufać obcym ludziom ${ }^{53}$. Po wejściu do szpitala ekipa przyglądała się na bieżąco wszystkim przypadkom i wybierała „medialnych” pacjentów, którzy byli otwarci i dawali się przekonać do tego projektu. Jak ubolewa producent, nie mieli wtedy środków, żeby kilka ekip równocześnie towarzyszyło kilku bohaterom, jak w The Great Ormond Street Hospital. Na stronie internetowej producenta czytamy: Przed kamera pojawiaja się w serialu pacjenci i lekarze tego szpitala, a ich losy i emocje sa głównym tematem filmów. W naszym serialu głównie chodzi o psychologiczna, a nie sensacyjna zawartość kolejnych odcinków. Nie można dopuścić do epatowania tragediami ludzi. To „,bycie razem”, a nie czekanie na dramat jest tworzywem filmów. Szpital jest ttem prezentacji ludzkich losów, a nie celem ich prezentacji. Mamy w serialu pacjentów, którzy musieli poddać się transplantacji, spotykamy dziewczyny, które przechodziły skomplikowane operacje kręgostupa i wraz z ich rodzicami lękamy się o ich wynik. Wspólnie przeżywamy radość na ślubie jednego z lekarzy, również razem niepokoimy się o losy odrzuconego przez matke noworodka. Jesteśmy razem z niektórymi bohaterami w ich domach, razem z nimi odbywamy podróże do naszego szpitala ${ }^{54}$.

„Duchowym ojcem” tego typu seriali w TVP1 był Andrzej Fidyk, szef redakcji dokumentu, znakomity dokumentalista (Defilada, Rosyjski striptiz, Carnaval, Kiniarze z Kalkuty), który powiedział: Uczestniczac w międzynarodowych konferencjach dokumentalistów, miałem wrażenie, że świat oszalat na punkcie nowego gatunku. Postanowiłem, że zrobimy w Jedynce nasza własna docusoap ${ }^{55}$. Na przełomie lat 1998-1999, kiedy pierwsze odcinki Szpitala ... były już zmontowane, Andrzej Fidyk rozpoczął, jako producent, prace nad 24-odcinkowym Pierwszym krzykiem, którego emisja zaczęła się 5 września 1999 r. Pierwszy krzyk, wyreżyserowany według własnego scenariusza przez Wojciecha Szumowskiego, opowiadał o życiu kilkunastu rodzin spodziewających się dziecka. Zrealizowany dla TVP1 serial rozgrywa się w dużej mierze w szpitalu, ale ekipa filmowa towarzyszyła też kilkunastu parom (w maju i czerwcu 1999 r.) podczas rodzinnych przygotowań do przyjęcia dziecka, tworząc tym samym niejako domowe pamiętniki z ostatnich dni przed rozwiązaniem. Prawdopodobnie po raz pierwszy polski reżyser wkroczył z kamerą do sali porodowej, by uczestniczyć w jednym z najbardziej osobistych zdarzeń w ludzkim życiu. Wiedzieliśmy, że ten temat będzie widza obchodził. Chyba nie ma innego wydarzenia, poza śmiercia, które byłoby wspólne wszystkim ludziom. Chodziło o to, żeby nasz serial nie był obojętny dla widzów - mówił Wojciech Szumowski ${ }^{56}$ i dodawał, że serial stanowił dla niego wyzwanie, gdyż nie jest łatwo opowiadać o losach ludzi z odcinka na odcinek. Pierwszy krzyk powstawał w Szpitalu im. R. Czerwiakowskiego, zwanym przez krakowian szpitalem na Siemiradzkiego. Tytuł serialu przyszedt mi do głowy, gdy śledzac nakręcone przez operatora zdjęcia, ustyszałem wyjaśnienie lekarza: ,pierwszy krzyk to pierwszy oddech dziecka, które łapiąc powietrze, rozplątuje sobie zasupłane $w$ matczynym łonie 
plucka”. Uznałem to za fascynujące-tapanie oddechu równoznaczne z łapaniem życia-powiedział reżyser.

Można przypuszczać, że wpływ na realizację tego projektu miała inspiracja zagranicznymi produkcjami i chęć odpowiedzenia na wyzwania stawiane przez światowe mody medialne. Polski nadawca - jak wynika z ówczesnych materiałów prasowych Telewizji Polskiej - miał świadomość, że „serial dokumentalny” jest gatunkiem szturmem podbijającym rynek filmowy na świecie, coraz częściej wygrywającym z filmami fabularnymi i programami rozrywkowymi ${ }^{57}$. W marcu tego samego roku Arte, jak wspomniałam, wyemitowała serial o podobnej tematyce Geburtsstation (prod. Arte, SFB, Zero Film). Reżyser zastrzegał jednak, że Pierwszy krzyk nie był kalką. Wybraliśmy świadomie miejsce i temat, bowiem narodziny budza wiele emocji. Nie pomyliliśmy się - kiedy w grę wchodziła niepewna przyszłość dziecka albo gdy matki trafiaty do Domu Samotnej Matki, urywaty się telefony - widzowie chcieli pomagać. BBC zrealizowało serial o porodach dopiero dwa lata po nas ${ }^{58}$. Wojciech Szumowski, przystępując do realizacji telenoweli, miał już na swoim koncie kilka interesujących filmów dokumentalnych i Nagrodę Główną za film Kraina złudzeń zdobytą w 1996 r. na Festiwalu Mediów „Człowiek w zagrożeniu" w Łodzi.

Liczba telenowel dokumentalnych z trzech w roku 1999 r. wzrosła w roku następnym aż do siedmiu. Najlepszym rokiem był 2004, kiedy wyprodukowano ich dziewięć ${ }^{59}$. Zaczęły one tworzyć swoistą socjograficzną mapę Polski. Jednak już w latach 2005-2008 impet produkcyjny osłabł - realizowano od jednego do trzech nowych tytułów rocznie. W roku 2009 i 2010 nie wyprodukowano żadnej klasycznej $\mathrm{w}$ formie telenoweli dokumentalnej, chociaż realizowano cykle w stylu docusoapowym. Lata 2011-2019 to ponownie okres produkowania od jednego do trzech tytułów rocznie. Wyjątkowy był w tym względzie rok 2015, kiedy pojawiło się pięć telenowel dokumentalnych, oraz 2016, w którym powstawały jedynie kontynuacje.

W historii polskiej telenoweli dokumentalnej kilka seriali wyróżniło się na tle innych. Kochaj mnie (2002, TVP2 ) Atheny Sawidis i Grzegorza Siedleckiego o dzieciach czekających na adopcję wyszedł poza ramy istnienia ekranowego i zaczął żyć własnym życiem - stał się w pewnym sensie instytucją i przekształcił w swego rodzaju magazyn interwencyjny. Niektóre właściwie w całości stanowiły idea placement i propagowały akcje istotne społecznie: S.O.S.! Dzieciom (2007) pomoc dzieciom pokrzywdzonym przez los; Operacja życie (2011) - serial objęty honorowym patronatem Ministra Zdrowia, pokazujący, jak ważny jest problem transplantacji; Moje 600 gramów szczęścia (2015) - przybliżający problemy i potrzeby wcześniaków oraz ich rodzin. Największe kontrowersje spośród telenowel dokumentalnych wywołał 22-odcinkowy serial Ireny i Jerzego Morawskich Ballada o lekkim zabarwieniu erotycznym (2003, TVP1) o rekrutowaniu i zatrudnianiu dziewcząt jako atrakcji prowincjonalnych dyskotek, za którego emisję Krajowa Rada Radiofonii i Telewizji nałożyła karę na TVP. Najwięcej telenowel dokumentalnych powstało w telewizji publicznej na zamówienie Programu 1 i Programu 2. Seriale te liczyły od kilku do ponad 170 odcinków (Kochaj mnie). W latach szczytowej popularności najczęściej były nadawane w wieczornym w paśmie największej oglądalności. W przeważającej części ich twórcami byli znani i uznani dokumentaliści, reportażyści i dziennikarze oraz reżyserzy filmów fabularnych. Komentarze - podobnie jak w docusoap - w telenowelach dokumentalnych czytali 
znani aktorzy lub lektorzy. Z pierwszych w Polsce telenowel dokumentalnych największym zainteresowaniem cieszyły się Pierwszy krzyk (1999), Prawdziwe psy (2001, TVP1), Przedszkolandia i Kochaj mnie (2002, TVP1).

Jeśli chodzi o inne stacje telewizyjne, to na przykład TVN po raz pierwszy wyprodukowała telenowelę dokumentalną w roku 2000 (Centrum nadziei, producent wykonawczy Besta Film), Polsat - w 2006 r. (Gorzka miłość), HBO - w 2008 r. (Wyrok na życie), TLC - w 2013 r. (In vitro. Czekając na dziecko, prod. Endemol Polska). W MTV po raz pierwszy polska telenowela dokumentalna pojawiła się w roku 2014 (Teen Mom. Poland, prod. Telemark dla Viacom International Media Networks), a na kanale Discovery - w 2015 r. (Polscy truckersi).

Wśród polskich docusoaps dominuje tematyka trudna i poważna. Ich genezą była reakcja czujnych realizatorów na to, co się działo na rynku europejskim. Telenowele dokumentalne niewątpliwie pozwoliły realizatorom sprawdzić się w tym gatunku, skonfrontować go z rodzimymi realiami, uchwycić - mniej lub bardziej zniekształcony obraz polskiej rzeczywistości przełomu wieków.

Pojawienie się telenowel dokumentalnych w 1999 r. oznaczało, że polska telewizja nie pozostaje w tyle i z coraz mniejszymi opóźnieniami reaguje na to, co się dzieje na zjawiska mediach światowych. Z jednej strony może to być odbierane jako uleganie globalnym modom mediowym lub bezrefleksyjna pogoń za zyskiem, a z drugiej - jako trzymanie ręki na pulsie, umiejętność odnalezienia się w nowym, nurcie. Jednak przede wszystkim świadczyło to o obyciu polskich dokumentalistów z rynkiem europejskim i ich otwartości na nowe wyzwania ${ }^{60}$. Jerzy Uszyński twierdził, że telenowela dokumentalna spełniła dość istotną funkcję w strategii programowej telewizji publicznej, doskonale wpisując się w dokumentalne pasma wieczorne, jakie Program 1 i Program 2 starały się wypromować, różnicując swoją ofertę zdominowaną wcześniej przez filmową fikcję. Doku-nowela zaspakajała więc głód Prawdy i obserwacji życia, jaki z natury towarzyszy przekazowi telewizyjnemu i którego istnienie ujawnił choćby Andrzej Fidyk, podejmując swego czasu decyzję uruchomienia cyklu „Czas na dokument” ${ }^{61}$. Zdaniem Uszyńskiego była to forma dokumentu z punktu widzenia ekonomicznego możliwa do udźwignięcia dla nadawcy, miała szansę odcisnąć się w zbiorowej świadomości o wiele mocniej niż pojedyncze filmy dokumentalne. Natomiast Mirosław Przylipiak dość optymistycznie dostrzegał w telenoweli dokumentalnej (...) kompromis między niedawno objawionym apetytem widowni na lekkostrawne, komercyjnie przyprawione obrazy rzeczywistości a właściwa polskiemu dokumentalizmowi tradycję artyzmu, powagi i stużby publicznej ${ }^{62}$.

Docusoap i telenowela dokumentalna mają strukturę opery mydlanej - gatunku wymarzonego przez producentów i nadawców telewizyjnych, ponieważ jest tani (ze względu na niskie standardy produkcyjne) i przywiązuje na długi czas ${ }^{63}$ rzeszę wiernych widzów, co jest z kolei istotne ze dla sponsorów i reklamodawców, zaś dla nadawców - w czasach, kiedy istnieje tak wiele stacji komercyjnych, z których prawie każda ma własną operę mydlaną - jest ważny ze względu na wskaźniki oglądalności. Docusoap bardzo dużo przejęła od opery mydlanej, jednak w tym kontekście pojawia się kilka wątpliwości. Czy osiągnęła status równy temu, jaki opera mydlana ma w wielu krajach? ${ }^{64} \mathrm{Czy}$ stała się podobnym do niej fenomenem i czy przez to można jej przypisywać równie duże znaczenie ekonomiczne? Z jednej strony nie osiągnęła tak znaczących wskaźników oglądalności jak opera myd- 
lana ${ }^{65}$ i rozmiarów tasiemcowych seriali ${ }^{66}$, ale z drugiej strony odegrała pewną rolę. Roger Graef napisał: po raz pierwszy dokument telewizyjny zaczą się regularnie przez wiele lat pojawiać wśród brytyjskich programów o najwyższej ogladalności. Dokumenty znalazły się w końcu w centrum ramówki ${ }^{67}$. Faktycznie, jeden odcinek Vet School (BBC) miał w 1996 r. 10 mln widzów ${ }^{68}$, odcinek The Cruise (BBC, 1998) zgromadził przed telewizorami około $11 \mathrm{mln}^{69}$, a jeden odcinek Driving School (BBC1) pokazany 15 lipca 1997 r. obejrzało 12,45 mln widzów, co stanowiło około 53 proc. całej publiczności ${ }^{70}$. Druga wątpliwość dotyczy warunków polskich: czy sama telenowela (nie mówiąc już o telenoweli dokumentalnej) miała i ma tak duże znaczenie dla telewizyjnej ramówki, jak opera mydlana np. w Wielkiej Brytanii, gdzie cały program dnia był na przełomie wieków układany pod jej kątem? ${ }^{71}$ Na pewno są widzowie, którzy od lat we wtorkowe wieczory włączają telewizor tylko po to, by w TVP2 obejrzeć kolejny odcinek M jak miłość. Tylko czy redaktorzy układający ramówkę planowali w ramach tzw. emisji wiązanej promocję innego programu, jak miało to miejsce właśnie w Wielkiej Brytanii? Z samej analizy programu telewizyjnego trudno wywnioskować, jak to jest dzisiaj w dobie tak popularnej telewizji nielinearnej ${ }^{72}$, ale w czasach, kiedy telenowela zdobywała w Polsce popularność, ramówki polskich stacji telewizyjnych były niestabilne. Programy z różnych powodów „wędrowały” po ramówce w ciągu dnia i tygodnia. $Z$ tego względu trudno było wprowadzać wiązaną promocję programów. Jeśli chodzi o telenowele dokumentalne, ramówka w ogóle nie dostarcza dowodów na istnienie takiego mechanizmu. Należy jednak podkreślić, że polskie telenowele dokumentalne, podobnie jak docusoap w innych krajach, w okresie rozkwitu były najczęściej nadawane w paśmie największej oglądalności. We wrześniu 2006 r. jedna z najdłużej nadawanych telenowel dokumentalnych Kochaj mnie została przesunięta z godziny 21.00 na 19.30 (emisja we wtorki). Z jednej strony mogłoby to świadczyć o tym, że ma ona swoich widzów i nie musi ich „dziedziczyć” po atrakcyjnej operze mydlanej, gdyby nie to, że 19.30 była niewątpliwie mniej korzystnym pasmem niż 21.00, choćby ze względu na emisję Wiadomości (godz. 19.30, TVP1) i Faktów (godz. 19.00, TVN), a jest to jednak ciągle pasmo sąsiadujące z pasmem opery mydlanej (M jak miłość, ówcześnie emisja o godz. 20.05).

W Polsce nie rozgorzała wśród dokumentalistów i nadawców tak gorąca jak np. we Francji dyskusja na temat zagrożeń, jakie niesie dla dokumentu telenowela dokumentalna i w ogóle reality TV, chociaż pojawiło się kilka głosów krytycznych. Natomiast realizatorzy polskich telenowel dokumentalnych podkreślali oczywiście jej rolę pozytywną. Telenowela dokumentalna podbija publiczność telewizyjna na całym świecie. Losy zwyklych ludzi stają się dziś bardziej interesujące niż fikcyjnych postaci. Myślę, że to próba zachowania równowagi w świecie, w którym dominuje fikcja-mówił w 1999 r. Wojciech Szumowski. Wtórował mu Andrzej Fidyk: Ten gatunek udowodnit, że nic tak dobrze nie robi filmowej opowieści jak możliwość rejestrowania uptywajacego czasu. Kino dtugo szukało sposobu, by pokazać uptyw czasu wedtug innego klucza niż wytacznie za pomoca retrospekcji. W dokumentalnej telenoweli ten problem rozwiazuje kamera. Po prostu wszystko dzieje się na naszych oczach. Fakt, że nasi bohaterowie naprawde maja konkretne adresy, a widzowie moga nawet ich odnaleźć i podyskutować o tym, co im się przydarzyło, daje poczucie uczestnictwa w zdarzeniach, które śledza na ekranie. Skojarzenie z reality show, wydawałoby się oczywiste, jest jednak błędne. Bohaterowie wszelkich programów tego 
typu zamykani sa bowiem w sztucznie odseparowanym od rzeczywistości środowisku. Nasi pozostaja we własnym otoczeniu, a my filmujemy ich codzienność. Jednym słowem: kawat prawdziwego życia ${ }^{73}$.

Ciekawym aspektem produkcyjnym telenoweli dokumentalnej, na który zwracali uwage praktycy, jest to, że w Polsce w zasadzie nie mieliśmy klasycznej docusoap w rozumieniu brytyjskim, dlatego że tak jak telenowela fikcjonalna, zakłada ona śledzenie losów tych samych bohaterów przez dłuższy czas - pół roku, rok, sezon (44 odcinki). W ramach serii oglądamy znane postacie, które spotykają się z innymi ludźmi, ale główne dramatis personae są te same. Tego typu docusoap wymaga jednak bardzo długiego researchu i wyboru bohaterów, co pociąga za sobą wysokie koszty. Jak powiedział w 2006 r. Stanisław Krzemiński: W Polsce na ten etap przygotowawczy nigdy nie było środków w żadnej ze stacji. Nie ma u nas też kultury researchu, takiej jaka mają Anglicy, ani nie ma reżyserów castingu dokumentalnego, którzy posiadaja szósty zmyst do znajdowania - jak my to w branży mówimy - naturszczyków telewizyjnych, którzy maja pewna charyzmę niezależna od zawodu, jaki wykonuja ${ }^{74}$.

Klasyczna, porządnie zrobiona docusoap wymaga dużych nakładów nie tylko na sprzęt, jak w przypadku Clubschiff, ale przede wszystkim na dokumentację. Krzemiński mówił, że jeżeli realizator chce robić docusoap o lekarzach, to powinien szukać lekarza, a nie szpitala, a jeśli o strażakach, to strażaków, a nie remizy. Jeśli przykładowo odcinek docusoap kosztuje 80 tysięcy już $w$ realizacji, z tego $w$ kosztorysie na dokumentacje jest $n p .5 \%$ budżetu, to na to, żeby znaleźć takich bohaterów, np. lekarzy, którzy ,, uciagna sezon”, czyli 44 odcinki, trzeba wydać nie 5\%, ale np. 25\%. Trzeba bowiem rzetelnie przejechać z kamera cały kraj, szukając różnych ludzi, różnych specjalności, a potem sprawdzajac jeszcze, czy przełożeni danego lekarza wydadza zgodę itd. To jest roczna praca, która stacja musi zaakceptować budżetowo i tę dokumentację albo stacja, albo producent - prefinansować. W naszych warunkach taka dokumentacja pótroczna kosztuje 200-300 tysięcy złotych. Żaden producent zewnętrzny nie wyłoży w ciemno takich pieniędzy, bo co będzie, jeśli się takiego człowieka nie znajdzie. To jest ryzyko. Jeśli stacja ma ryzykować 200, 300 czy 400 tysięcy złotych na dokumentację, to woli zrobić pewniaka, czyli kupić format lub zaakceptować scenariusz przewidywalny, tzn. taki, który zakłada, że zaszywamy się w ciekawym miejscu i tam szukamy bohaterów ${ }^{75}$.

Jeśli nie wszystkie, to zapewne większość polskich telenowel dokumentalnych w pierwszej dekadzie XXI w. powstawało w ten właśnie sposób i to też - przynajmniej z realizatorskiego punktu widzenia - stanowiło o ich odrębności wobec ówczesnych docusoaps, nie mówiąc już o częstym sprzeniewierzaniu się docusoapowej zasadzie: emisja telewizyjna po zakończeniu zdjęć. Zresztą w Wielkiej Brytanii sytuacja też nie do końca była tak prosta. Większość komentatorów uważała że docusoap jest gatunkiem tanim ${ }^{76}$. W 1999 r. Winston twierdził, że kosztuje ona jedynie 65000 funtów za odcinek, czyli około jednej piątej ceny godzinnego odcinka popularnego serialu obyczajowego ${ }^{77}$. Jednocześnie sam narzekał, że system telewizji brytyjskiej mniej lub bardziej wymagał sensacyjnych materiałów od wszystkich dokumentalistów i coraz częściej odmawiał finansowania dokumentacji oraz przygotowań na odpowiednim poziomie. To zachęcało do manipulacji głównymi postaciami docusoap, a praktyka ta rozlewała się na pozostałe obszary bardziej tradycyjnych prac dokumentalnych, które coraz mocniej się tabloidyzowały. 
Dodawał też, że większość brytyjskich dokumentów telewizyjnych realizowały małe niezależne firmy produkcyjne, które - aby uzyskać zlecenia od nadawcy często obiecywały więcej niż mogły dostarczyć, a potem fabrykowały to, czego nie mogły sfilmować. Jednak - jak pamiętamy - pojawiały się też głosy dowodzące wręcz czegoś przeciwnego, vide opisywany przez Fritza Wolfa przypadek kosztownego serialu Clubschiff.

W kontekście docusoap i telenoweli dokumentalnej rzadko mówi się otwarcie o wynagrodzeniu finansowym, jak np. w rozmaitych reality shows, gdzie uczestnicy walczą o pieniądze (Big Brother) lub wartościowe nagrody - atrakcyjną wycieczkę (Łowcy przygód) czy własną restaurację (Hell’s Kitchen). Można jednak przypuszczać, że i takie gratyfikacje się zdarzają. Dziennikarka „Wprost”, komentując w 2000 r. pierwsze polskie telenowele dokumentalne, pisała: Watpliwość wielu widzów wzbudzaja motywy uczestniczenia $w$ realizacji telenoweli postaci, które niejednokrotnie godza się pokazywać swoje upokorzenie, cierpienie i biedę. Tajemnica poliszynela jest, że za zgodę na udziat w zagranicznych docusoaps bohaterom ptaci się spore sumy. Polscy realizatorzy nie przyznają się jednak do wynagradzania swoich ,,aktorów”. Zwracaja jedynie koszty przejazdu czy opłaty za korzystanie $z$ prądu $w$ trakcie nagrań $w$ ich mieszkaniu ${ }^{78}$. Niewątpliwie jednak uczestnicy tych programów w perspektywie widzieli konkretną korzyść. Instytucje dostrzegały możliwość rozpropagowania swoich idei i znalezienia potrzebnej im pomocy. W Kochaj mnie oprócz stałego prezentowania dzieci, które czekały na nowe rodziny, pojawiały się rozmaite apele o dofinansowywanie konkretnych placówek opiekuńczych, propagowane były idee np. rodzin zastępczych czy rodzinnych domów dziecka. Udział firm w docusoap stanowił znakomitą okazję do zareklamowania się. Tanie linie lotnicze EasyJet, które w 1999 r. były tematem docusoap Airline (ITV), pozwoliły na prawie pełny dostęp do swoich spraw i pracowników. Ryzyko, że kamera zarejestruje rozmaite incydenty z pasażerami narzekającymi z powodu złej obsługi, niewygody, zagubionych bagaży etc., było wliczone w koszty osiągnięcia sporego darmowego rozgłosu. Dyrektor EasyJet stwierdził: Logika tego biznesu była prosta: nie sprzedajemy naszych usług przez biura podróży, więc wszyscy nasi klienci musza do nas dotrzeć - 70 proc. za pośrednictwem naszej strony internetowej, a reszta przez informację telefoniczna. Dlatego musieliśmy znaleźć tak wiele sposobów jak to możliwe, by utrzymywać markę EasyJet w świadomości klientów. Każdego roku wydawaliśmy miliony funtów na reklamy prasowe $i$ postery, ale nigdy na reklamę telewizyjna, więc serial „Airline” dat nam możliwość wejścia na ekrany ${ }^{79}$.

\section{Podsumowanie}

Co ten gatunek dał nadawcom telewizyjnym? W kolebce docusoap, Wielkiej Brytanii, jej zasługą było niewątpliwie statystyczne zwiększenie wskaźników oglądalności programów faktualnych. Dla nadawców była to zasługa tym większa, że oglądalność rosła, a koszty produkcji - nie, co w stawiającej na oszczędzanie współczesnej telewizji jest sprawą pierwszorzędną ${ }^{80}$. Co więcej, popularność wśród publiczności programy te zyskały bez pokazywania zbrodni czy przemocy seksualnej. Oczywiście, wzrost był jedynie statystyczny, bo dotyczył oglądalności programów faktualnych, nazywanych jednak dokumentalnymi, do których zali- 
czono też docusoap. Wprawdzie do roku 1998 programy te osiągały w Wielkiej Brytanii od 8 do 12 mln widzów, jednak nie miało to większego znaczenia dla samego dokumentu. Brian Winston twierdził, że oglądalność filmów dokumentalnych pozostawała relatywnie niska, a ich publiczność licząca powyżej $5 \mathrm{mln}$ widzów wciąż była wyjątkiem. Zdaniem wielu obserwatorów, pierwsze formy dokumentalne, które zostały naprawdę docenione przez masową publiczność, jak na ironię zabijały tradycję Griersonowską. Często na początku XXI w. można było się spotkać z poglądem, że wraz z docusoap programy faktualne po raz pierwszy trafiły do pasma prime-time i mogły rywalizować ze swymi fabularnymi odpowiednikami, czyli z operą mydlaną ${ }^{81}$. Również tej diagnozie Winston zaprzeczał, pisząc, że dokumenty trafiły do pasma najlepszej oglądalności już w latach 80. i to właśnie wtedy, a nie wraz z ekspansją docusoap, pojawił się problem „ogłupiającej” telewizji. Jednak bez wątpienia docusoaps w pewnym momencie tak podniosły statystykę i tak opanowały ramówki, że pojawiło się wrażenie nadmiaru materiałów dokumentalnych w telewizji ${ }^{82}$. Dla Winstona ucieczka z tradycyjnego elitarnego getta nielicznej publiczności filmu dokumentalnego była sporym osiągnięciem. Doceniał on też produkcje docusoapowe, które w większości nie ukazywały zwykłych ludzi przez pryzmat ich problemów lub w kategoriach ofiar systemu społecznego, a przy tym przełamywały tradycyjną powagę dokumentów, wykorzystując humor, jaki niosły przedstawiane w docusoap opowieści. Zgadzał się z zarzutem, że docusoaps wyznaczyły wzór przyciągania publiczności tanim kosztem, co doprowadziło do powszechnego ograniczania środków i wzrostu oczekiwań dotyczących wskaźników oglądalności ze strony zarządów stacji. Jeśli jednak gatunek ten nie osiągnąłby takiego sukcesu, dokument zacząłby znikać z ramówek brytyjskich. Zdaniem Winstona to tradycyjnie niewielka publiczność mogła się przyczynić do ograniczania środków na dokument, a nawet do zagrożenia jego obecności w ramówce. W tym sensie docusoap prawdopodobnie była ceną przetrwania ${ }^{83}$.

Wpływ docusoap i gatunków reality TV na film dokumentalny jest w wielu krajach dość podobny. Zmusiły one niejako do przyjęcia bardziej formy sensacyjnej, przy czym nie bez znaczenia była tu tendencja do oszczędzania na kosztach etapu dokumentacyjnego i przygotowaniach produkcyjnych, na co narzekali zarówno Brytyjczycy, Niemcy, jak i Polacy. Pojawiały się więc filmy niedbałe, ale sensacyjne i szokujące. Jeśli chodzi o polskie telenowele dokumentalne, których geneza tkwi w dużej mierze w naśladownictwie obcych sprawdzonych wzorów, to nie wydaje się, by miały być bądź były ratunkiem dla dokumentu telewizyjnego. Niewątpliwie i u nas podniosły statystykę oglądalności programów faktualnych, ale nie dotyczy to tak naprawdę filmów dokumentalnych. Zresztą taki wzrost oglądalności programów dokumentalnych nie jest trudny do osiągnięcia, gdyż coraz częściej dokumentem nazywa się wszystko, co nie jest newsem i filmem fabularnym (filmowe eseje, reportaże, portrety, docu-crime i docusoap). Jest to albo przejaw telewizyjnej potrzeby obiecywania widzom autentyczności, albo po prostu pojęciowe zagubienie w strumieniu telewizyjnym. Telenowela dokumentalna nie tyle zainteresowała jej miłośników filmem dokumentalnym, ile stworzyła im iluzję obcowania z dokumentem. Klasyczne dokumenty wciąż powstają i będą powstawać, mają bowiem swoją publiczność, festiwale i są wprowadzane do repertuaru kin. Zresztą w Polsce to nie telenowela dokumentalna - nawet w okresie największego rozkwitu - podniosła wskaźniki oglądalności programów faktualnych; zdecydowało o tym raczej przesu- 
nięcie specyficznych filmów dokumentalnych w ramówce $\mathrm{z}$ bardzo późnych godzin nocnych do pasma największej oglądalności. Taką politykę repertuarową stosował z powodzeniem ówczesny szef redakcji dokumentu PTVP 1 Andrzej Fidyk. Wymyślone przez niego cykle Miej oczy szeroko otwarte ${ }^{84}$, Czas na kontrowersyjny dokument czy Ciag dalszy nastapi osiągały rekordy oglądalności. Niektórzy obserwatorzy telewizji publicznej twierdzili nawet, że widownia pierwszego cyklu bywała czasami tak samo liczna jak Wiadomości ${ }^{85}$. Jeśli rzeczywiście tak było, to wpływ na to miał nie tylko czas emisji czy duży rozrzut tematyczny tych cykli ${ }^{86}$, ale też styl i forma prezentowanych dokumentów. Były to najczęściej filmy sensacyjne, kontrowersyjne, przełamujące tabu. Niemniej Fidyk pokazał, że pewien rodzaj dokumentu może być emitowany o godzinie 20.00. Być może wystarczyło zrobić drugi krok i obok ,atrakcyjnych" dokumentów umieścić w stałym paśmie prime-time najwyższej próby dokumenty polityczne i historyczne.

Docusoap, osiągnąwszy gwałtowną przewagę w dziedzinie programów faktualnych w Wielkiej Brytanii w latach 1996-2000, a telenowela dokumentalna w Polsce w latach 1999-2004, ma już ugruntowaną pozycję wśród telewizyjnych gatunków i formatów reality, które nadal powstają i próbują przyciągnąć uwagę widzów. Realizatorzy sięgają po tę formę w miarę regularnie, choć nie tak licznie jak wcześniej. Przewidywał to w 2003 r. Richard Kilborn: Docusoaps, jak wszystkie inne formaty telewizyjne, okazały się nieodporne na kaprysy mody. Po krótkim zabłyśnięciu w światłach rampy, podczas którego byty aktywnie (ktoś powie: bezwzględnie) eksploatowane przez redaktorów zamawiajacych, teraz zajęty spokojnie swoje miejsce obok wielu innych formatów faktualnych, które zabiegaja o uwage konsumentów na coraz bardziej zatłoczonym rynku telewizyjnym ${ }^{87}$. Podobnie w odniesieniu do przyszłości telenoweli dokumentalnej przed laty prognozowała pisząca te słowa: Sprawdziliśmy, poznaliśmy, mamy własne i teraz - w miarę potrzeb - możemy odstawiać na pótkę lub z niej zdejmować ${ }^{88}$.

BEATA KOSIŃSKA-KRIPPNER

${ }^{1}$ Terminu „faktualne” używam tu na określenie form i programów, które nie są fikcjonalne, ale też trudno je uznać za dokumentalne. Ogólniejszy termin obejmuje zatem zarówno dokumenty, wobec których widz ma tradycyjne oczekiwania, jak i nowe, zorientowane bardziej rozrywkowo, formy hybrydowe, które tych oczekiwań nie spełniają lub jedynie to markują.

${ }^{2} \mathrm{~W}$ niniejszym tekście wykorzystałam badania i obserwacje czynione przeze mnie na bieżąco w momencie powstawania i w okresie największego rozkwitu telenoweli dokumentalnej. W tym sensie artykuł ma charakter historyczny, jednak z koniecznymi odwołaniami do współczesności.

${ }^{3}$ Na temat reality TV zob. m.in.: M. Kavka, $R e$ ality TV, Edinburgh University Press, Edinburgh 2012; J. Deery, Reality TV, Polity Press, Cambridge 2015.
${ }^{4}$ Zob. M. Kavka, dz. cyt., s. 61.

${ }^{5} \mathrm{O}$ tym skandalu pisze wielokrotnie w swoich pracach Brian Winston, m.in. w Lies, Damn Lies and Documentaries, British Film Institute, London 2000 i w The Primrose Path: Faking UK Television Documentary, ,Docuglitz” and Docusoap, http://www.screeningthepast.co$\mathrm{m} / 2014 / 12 /$ the-primrose-path-faking-uk-television-documentary-docuglitz-anddocusoap/ (dostęp: 14.01.2020); zob. też: B. Kosińska-Krippner, Mock-documentary a dokumentalne fatszerstwa, „,Kwartalnik Filmowy" 2006, nr 54-55, s. 190-210.

${ }^{6} \mathrm{~S}$. Brenton, R. Cohen, Polowanie na ludzi. Za kulisami reality $T V$, tłum. L. Stawowy, Warszawskie Wydawnictwo Literackie Muza S.A., Warszawa 2004, s. 36.

${ }^{7}$ Zob. D. Hobson, Soap Opera, Polity Press, Cambridge 2003, s. 56. 


\section{BEATA KOSIŃSKA-KRIPPNER}

${ }^{8}$ Zob. R. Kilborn, Staging the Real. Factual TV Programming in the Age of Big Brother, Manchester University Press, Manchester 2003, s. 90 .

9 A. Jwarg, Points of Fact, ,Time Out” 1991, 18-21.09.1991, s. 146.

${ }^{10}$ Wyprodukowany w Wielkiej Brytanii przez Paula Watsona i wyreżyserowany przez Franca Roddama 12-odcinkowy serial The Family (BBC1, 1974) pokazuje losy należących do klasy pracującej członków rodziny Wilkins $\mathrm{z}$ Reading. Ten dokumentalny serial w stylu fly-on-the-wall, uważany za prekursora brytyjskiej reality TV, śledzi szczegóły z codziennego życia rodziny, aż do ślubu jednej z córek, w którym biorą udział także fani i paparazzi. Zdaniem Richarda Kilborna, który uznaje The Family za pracę pionierską, serial antycypuje późniejszą docusoap przynajmniej tak długo, jak długo są brane pod uwagę zasady strukturalne.

${ }^{11}$ Zob. np. K. Macdonald, M. Cousins, Imaging Reality, Faber \& Faber, London 1996.

${ }^{12}$ M. Lünenborg, Journalism as Popular Culture. Docu-Soap: A new Genre Crossing the Border of Fact and Fiction, referat wygłoszony na konferencji IAMCR w Barcelonie w 2002 r., s. 11, http://www.portalcomunicacion.com/bcn2002/n_eng/programme/prog_ind/papers/1/pdf/1006_lunen.pdf(dostęp: 7.01.2020).

${ }^{13}$ L. Hachmeister, Im Supermarkt der Wirklichkeit. Zur Ökonomie des Dokumentarfernsehens, „Funkkorrespondenz” 1998, nr 45, s. 1-5.

14 J. K. Ruoff, ,A Bastard Union of Several Forms". Style and Narrative in ,An American Family", w: Documeting the Documentary, red. B. K. Grant, J. Sloniowski, Wayne State University Press, Detroit 1998, s. 289-299.

${ }^{15}$ M. Lünenborg, dz. cyt., s. 5.

${ }^{16}$ A. Keppler, Wirklicher als die Wirklichkeit? Das neue Realitätsprinzip der Fernsehunterhaltung, Fischer, Frankfurt am Main 1994, s. 7-10.

${ }^{17}$ G. Bente, B. Fromm, Affektfernsehen. Motive, Angebotsweisen und Wirkungen, Leske + Budrich, Opladen 1997.

${ }^{18}$ M. Przylipiak, Poetyka kina dokumentalnego, Wydawnictwo Uniwersytetu Gdańskiego, Wydawnictwo Pomorskiej Akademii Pedagogicznej w Słupsku, Gdańsk - Słupsk 2004, wyd. II, s. 307.

${ }^{19}$ Przylipiak podaje jako przykład takiego historycznego filmu dokumentalnego Victory at Sea, współprodukowany przez Craiga Gilberta na początku lat 50 .

${ }^{20}$ R. Kilborn, dz. cyt., s. 94.

${ }^{21}$ Tamże, s. 95.
${ }^{22} \mathrm{~W}$ serialach The Vet i The Doctor ustanowiono - zdaniem Kilborna - charakterystyczne dla późniejszych docusoaps podejście. Obie produkcje polegały - tak jak docusoap - na zbliżeniu się do osób pracujących zawodowo i towarzyszeniu im podczas ich codziennych zajęć. Od „dojrzałych” docusoaps różniły się tym, że każdy z tych seriali koncentrował się tylko na jednej postaci, podczas gdy produkcje z gatunku docusoap wymagają większej obsady. W obu jednak występowała już - typowa dla docusoap - perspektywa naprzemienna, ukazująca głównego bohatera raz w środowisku zawodowym, a za chwilę w prywatnym, oba kładły duży nacisk na charakter i osobowość uczestników oraz próbowały wykorzystywać materiałyo większym znaczeniu społecznym, a przy montażu Mills i jego ekipa, starając się, by ich dokumenty były przystępne, zastosowali techniki, które są właściwe dramatowi telewizyjnemu, a nie dokumentowi. Zob. R. Kilborn, dz. cyt., s. 96.

${ }^{23}$ Zdaniem Briana Winstona już ramówka BBC1 z jesieni 1999 r. wskazywała, że moda na docusoap przemija. Z perspektywy roku 2012 Misha Kavka pisał, że po trzech, czterech latach osiągania najwyższych wskaźników oglądalności produkcja docusoap w późnych latach 90. równie gwałtownie zahamowała, jak wcześniej wystartowała, pozostawiając jednak trwały ślad. Zob. M. Kavka, dz. cyt., s. 61.

${ }^{24}$ G. Coles, Docusoap: Actuality and the Serial Format, w: Frames and Fictions on Television: The Politics of Identity within Drama, red. B. Carson, M. Llewellyn-Jones, Intellect Books, Exeter - Portland 2002, s. 27-40.

${ }^{25}$ D. Hobson, dz. cyt., s. 56.

${ }^{26}$ A. Bethell, A Job, Some Stars, and a Big Row, Media Watch '99, ,Sight and Sound”, London 1999, s. 14.

${ }^{27}$ B. Winston, dz. cyt., s. 54.

${ }^{28}$ S. Bruzzi, Docusoap, w: The Television Genre Book, red. G. Creeber, British Film Institute, London 2004, s. 132 (I wyd. 2001).

${ }^{29}$ F. Morrow, The Slippery Slope, ,Time Out”, 17-24.06.1998, s. 172.

${ }^{30}$ J. Mulholland, What's up Docs? „Guardian”, 26.01.1998, s. 7.

${ }^{31}$ J. Willis, Breaking Boundaries, w: From Grierson to the Docu-soap, red. J. Izod, M. Hibberd, R. Kilborn, University of Luton Press, Luton 2000, s. 102.

${ }^{32} \mathrm{P}$. Watson, I am like a Poacher (P. Watson interviewed by F. Verster), „DOX (Documentary Film Magazine)" 2000, nr 31, s. 10.

${ }^{33}$ R. Kilborm, dz. cyt., s. 99. Zob. również: M. Kavka, dz. cyt., s. 61. 
${ }^{34}$ A. Bethell, dz. cyt., s. 15.

${ }^{35}$ Zob. opinię Kilborna w: M. Hibberd, R. Kilborn, B. McNair, S. Marriot, P. Schlesinger, Consenting Adults? Broadcasting Standards Commision, London 2000, s. 115-116.

${ }^{36}$ R. Kilborm, dz. cyt., s. 99.

${ }^{37}$ Tamże, s. 58, 87

38 Tamże, s. 119.

${ }^{39}$ Pierwsza seria Abnehmen in Essen była jednym z największych docusoapowych sukcesów WDR i Arte. W marcu 2001 r. producent Carl-Ludwig Rettinger i reżyserka Claudia Richarz otrzymali niemieckiego „Oscara telewizyjnego" - 36. Nagrodę Adolfa Grimme 2000 za to, że - jak uzasadniło jury - potrafili bez voyeuryzmu i sztucznej dramaturgii w intrygujący sposób opowiedzieć historię z życia codziennego.

${ }^{40}$ Można przypuszczać, że na rozwój niemieckiej docusoap pozwoliły warsztaty Wahre Leben? zorganizowane w marcu 1999 r. przez Filmbüro NW i Dokumentarfilminitiative (dfi).

${ }^{41}$ F. Wolf, Alles Doku - oder was? Über die Ausdifferenzierung des Dokumentarischen im Fernsehen, LfM-Dokumentation, Bd 25, Düsseldorf 2003, s. 96.

42 F. Wolf, Plot, Plot und wieder Plot, http://www/epd.de/medien/1999/22leiter.htm (dostęp: 16.05.2007).

${ }^{43}$ [jb], Geburtsstation ist Ort für Fernsehserie. Arte zeigt „Docu-Soap” über Rudolf-Virchow-Klinikum, „Berliner Zeitung”, 4.03.1999, s. 25.

${ }^{44}$ F. Wolf, Alles Doku... dz. cyt., s. 97.

${ }^{45}$ M. Zöllner, Kulturdokumentationen im SWR. Formate und ihre Entwicklung, SWR Hauptabteilung Kultur-Fernsehen, Baden-Baden 2003, s. 6.

46 „Kressreport” 2004, nr 15, s. 41.

${ }^{47}$ Niektóre źródła - np. strona internetowa firmy Trinome, uważającej się za pioniera docusoap w Quebecu - podają, że pierwszą taką produkcją w tej prowincji jest było Pignom sur rue (1995-1999). Jednak zgodnie z przyjętą definicją, serial ten jest bliższy reality show i Trinome jest w Quebecu raczej pionierem tego gatunku, a nie docusoap.

${ }^{48}$ J. Ruoff, An American Family. A Televised Life, University of Minnesota Press, Minneapolis London 2002.

${ }^{49}$ M. Lünenborg, dz. cyt., s. 10.

${ }^{50}$ Rozmowa autorki ze Stanisławem Krzemińskim 14.11.2006 r.

${ }^{51}$ Tamże.

${ }^{52}$ M. Piwowar, Coraz mniej zahamowań, ,Rzeczpospolita" 2006, nr 72, s. $11 \mathrm{~A}$

${ }^{53}$ Rozmowa autorki, dz. cyt.
${ }^{54}$ Zob. http://www.besta.pl/szpital-dzieciatkajezus/ (dostęp: 14.01.2020).

55 J. Kobus, Big Górnik, „Wprost” 2001, nr 43, s. 110.

${ }^{56}$ A. Wrzesień, K. T. Nowak, Człowiek się rodzi, „Przekrój” 1999, nr 51-52, s. 18-19.

${ }^{57}$ Niewątpliwie dostęp ekipy filmowej do oddziału położniczego (wcześniej twierdzy nie do zdobycia nawet dla mężów pacjentek) był możliwy dzięki przemianom w polskim położnictwie, jakie zachodziły w latach 90 . w bardzo dużej mierze dzięki prowadzonej od 1994 r. akcji „Rodzić po ludzku”, uznanej przez specjalistów od public relations za jedno z najbardziej skutecznych działań medialnych tamtych lat.

${ }^{58}$ M. Piwowar, dz. cyt. Warto dodać, że w 1998 r. C5 Bazal zrealizował serial o liverpoolskim szpitalu położniczym Liverpool Mums.

${ }^{59}$ Liczby te odnoszą się do seriali spełniających kryteria telenoweli dokumentalnej zawarte w jej definicji. W tekście tym nie uwzględniono seriali, które w innych źródłach są wprawdzie określane mianem telenowel dokumentalnych, ale nie spełniają tych kryteriów i zostały uznane przez autorkę za kolejne hybrydy. I odwrotnie, uwzględniono seriale, które te kryteria spełniają, chociaż inne źródła określają je mianem seriali (a nie telenowel) dokumentalnych.

${ }^{60}$ Dla porównania, w czeskiej telewizji publicznej pierwsza docusoap pojawiła się w roku 2010. Zob. https://www.dokrevue.com/clanky/onthe-border-between-reality-and-fiction (dostęp: 15.01.2020).

${ }^{61}$ J. Uszyński, Dwa warianty doku-noweli, ,Zeszyty Telewizyjne" 2004, nr 4, s. 128.

${ }^{62}$ M. Przylipiak, Najnowsze tendencje dokumentalizmu TV, ,Zeszyty Telewizyjne” 2003, nr 1, s. 35 .

${ }^{63} \mathrm{~Np}$. brytyjska opera mydlana Coronation Street jest nadawana od 1960 r., Emmerdale - od 1972 r., a EastEnders - od 1985 r.

${ }^{64}$ Np. w USA, Wielkiej Brytanii, Holandii czy Australii.

${ }^{65}$ Jak podawała w 2001 r. Dorothy Hobson w monografii Soap Opera, w Wielkiej Brytanii każdego tygodnia około $32 \mathrm{mln}$ widzów oglądało w sumie 45 godzin oper mydlanych.

${ }^{66}$ Coronation Street czy amerykańska Moda na sukces mają już kilka tysięcy odcinków. W porównaniu z tym wynikiem docusoaps liczą ,zaledwie" od kilkunastu do kilkudziesięciu odcinków.

${ }^{67}$ R. Graef, A Tricky Business, „Television” 1999, kwiecień, s. 15.

${ }^{68}$ Podaję za: J. Dovey, Freakshow: First Person Media and Factual Television, Pluto Press, London 2000, s. 134. 


\section{BEATA KOSIŃSKA-KRIPPNER}

${ }^{69}$ Podaję za: S. Bruzzi, dz. cyt.

${ }^{70}$ Dane podaję za: B. Winston, dz. cyt., s. 54; zob. też: J. Dovey, dz. cyt., s. 135; M. Kavka, dz. cyt., s. 61.

${ }^{71}$ Opera mydlana zdobywała i zatrzymywała publiczność, zyskiwała omówienia w prasie, wywoływała polemiki, przynosiła dochody z reklam, wspierała etos służby publicznej oraz prowokowała dyskusje, rozważania, analizy i ciągle ewoluowała. Ponadto była ważnym nośnikiem przekazów etycznych, najpotężniejszym i najbardziej efektywnym pod względem nakładów gatunkiem telewizyjnym; dla widzów - rozrywką, a dla producentów i nadawców - biznesem.

${ }^{72}$ Chociaż, z drugiej strony, Polska znajduje się w gronie państw, w których spadek konsumpcji telewizji linearnej jest najmniejszy. W dwunastu badanych krajach europejskich wynosi on średnio 8,2 proc., a m.in. w Polsce oraz Wielkiej Brytanii między rokiem 2015 a 2018 odnotowano spadki mniejsze niż ta średnia. Zgodnie z najnowszymi danymi GlobalWebIndex, Polska zajmuje czwartą lokatę pod względem Web-Index widzów telewizji linearnej w Europie. Zob.: https:/www.warc.com/content/paywall/article/warcdatapoints-gwi/linear-tv-dominates-ineurope-but-online-content-is-challenging/127226 (dostęp: 15.01.2020) oraz https://tv.tvnmedia.pl/telewizja-linearna-dominuje-w-europie/ (dostęp: 15.01.2020).

${ }^{73}$ Cyt. za: J. Kobus, dz. cyt.
${ }^{74}$ Rozmowa autorki... dz. cyt.

${ }^{75}$ Tamże.

${ }^{76}$ Zob. np. B. Winston, dz. cyt., s. 54- 55 lub M. Kavka, dz. cyt., s. 62.

${ }^{77}$ Tenże, The Primrose Path... dz. cyt.

${ }^{78}$ A. Zwiefka, Transmisja z życia, ,Wprost” 2000, nr 17, s. 112-114.

${ }^{79}$ R. Webster, Planes and Boats in Train, „Observer", 27.08.2000, s. 5.

${ }^{80}$ Zob. m.in.: R. Boyle, L. W. Kelly, The Television Entrepreneurs: Social Change and Public Understanding of Business, Ashgate Publishing, Ltd., Farnham 2012, s. 36.

${ }^{81}$ Zob. np. S. Bruzzi, dz. cyt., s. 132.

${ }^{82}$ Zob. R. Coward, Too Many Flies on the Wall, all Wanting a Story, „Guardian”, 11.11.1996.

${ }^{83}$ B. Winston, dz. cyt., s. 55.

${ }^{84}$ Cykl ten rozpoczął 7 lutego 2000 r. film Dzieci Gai (Gaias Boern), reż. Bente Milton (Dania, 1998).

${ }^{85}$ Podaję za: T. Pikulski, Prywatna historia telewizji publicznej, Muza S.A., Warszawa 2002, s. 428.

${ }^{86}$ Dzieci Gai, Viagra, Piersi Mirandy, Rozwody po irańsku, Kulisy oscarowej nocy, Dream Girls, Tippi z Afryki, Jan Pawet II - Papiez Tysiaclecia.

${ }^{87}$ R. Kilborn, Staging... dz. cyt., s. 120.

${ }^{88}$ B. Kosińska-Krippner, Między fikcją a faktami. Docusoap po polsku, czyli telenowela dokumentalna, „Kwartalnik Filmowy” 2011, nr 75$-76,273-294$ 